\title{
PENGHAMBATAN KSANTIN OKSIDASE OLEH KOMBINASI EKSTRAK TEMPUYUNG (Sonchus Arvensis) DAN SALAM (Syzygium Polyanthum) PADA MENCIT HIPERURISEMIA
}

\author{
Muhtadi, Idi Retnani, Nurcahyanti Wahyuningtyas \\ Fakutas Farmasi Universitas Muhammadiyah Surakarta \\ Correspondence to: Muhtadi \\ Email :muhtadi@ums.ac.id
}

\begin{abstract}
Tempuyung (Sonchus arvensis) and salam (Syzygium polyanthum) leaves can lower uric acid levels were studied. The purpose of this research was to determine mechanism of combined of tempuyung and salam extracts to reduce uric acid levels by inhibiting xanthine oxidase in hyperuricemic mice. This research used completely randomized design using mice. Fifteen mice were made hiperuricemic by $250 \mathrm{mg} / \mathrm{kgBW}$ potassium oxonate p.o then the mice were divided into 3 groups. Group I induced $10 \mathrm{mg} / \mathrm{kgBW}$ allopurinol p.o as positive control, group II induced tempuyung-salam p.o each $100 \mathrm{mg} / \mathrm{kgBW}$ as the treatment group, group III induced $0.5 \mathrm{~mL} / 20 \mathrm{gBW}$ distilled water p.o as negative control. Liver was taken $4^{\text {th }}$ day after 2 hours induced potassium oxonate. Data inhibition xanthine oxidase activity was tested with Mann-Whitney. The result showed that the combination of tempuyung-salam extract each $100 \mathrm{mg} / \mathrm{kgBW}$ could inhibit xanthine oxidase activity of $51,16 \% \pm 2,76 \%$, while allopurinol $90,20 \% \pm 0,16 \% \quad(p=0.000)$.
\end{abstract}

Keyword: Hyperuricemia, Xanthine Oxidase, Sonchus arvensis, Syzygium polyanthum

\section{PENDAHULUAN}

Hiperurisemia adalah keadaan dimana terjadi peningkatan kadar asam urat darah diatas normal (Rose dan Kaye, 1997). Batas normal kadar asam urat pada manusia adalah 3-8 mg/ dL (Dipiro et al., 2008). Hiperurisemia terjadi akibat sintesis berlebihan asam urat dan kegagalan ginjal dalam mengeliminasi asam urat, atau kombinasi faktor-faktor tersebut (Rose dan Kaye, 1997). Hiperurisemia dapat diatasi dengan obat-obat urikosurik yang bekerja meningkatkan kliren ginjal dengan menghambat reabsorpsi asam urat pada tubulus. Selain itu dapat pula dilakukan dengan pemberian allopurinol yang bekerja menghambat sintesis ksantin oksidase pada dua tahap yaitu menghambat pembentukan ksantin dari senyawa hipoksantin dan menghambat pembentukan asam urat dari ksantin. Obat ini memiliki efek samping meliputi rash kulit, leukopenia, kadang-kadang gangguan gastrointestinal, dan dapat menimbulkan serangan akut pada awal terapi (Priyanto, 2008). Oleh karena itu, perlu dicari alternatif pengobatan yang lebih aman dan efektif.
Tempuyung (Sonchus arvensis) merupakan salah satu tanaman obat yang berkhasiat sebagai pemecah batu ginjal dan pelancar air seni (Winarto, 2004). Menurut Wardani (2008) secara in vitro daya inhibisi ksantin oksidase pada ektrak air tempuyung sebesar 14,46\%, ekstrak etanol tempuyung sebesar $11,2 \%$, sedangkan flavonoid sebesar $11,13 \%$. Kandungan flavonoid daun tempuyung berupa 5,7,3',4'-tetrahidroksi flavon (luteolin), 5,7,4'-trihidroksi flavon (apigenin), luteolin 7-O-glukosida, dan apigenin 7-O-glukosida diduga dapat menurunkan kadar asam urat melalui penghambatan kerja enzim ksantin oksidase (Cos et al., 1998; Djunaedi dkk., 2003).

Tanaman lain yang dimanfaatkan dalam pengobatan asam urat adalah daun salam. Kandungan utama daun salam meliputi saponin, triterpen, flavonoid total sebesar $0,19 \%$, tanin, polifenol, dan alkaloid (Sudarsono et al., 2002; Muhtadi dkk., 2010). Flavonoid kuersetin dan miresetin pada tanaman salam diduga berkhasiat dalam menghambat kerja ksantin oksidase (Schemeda et al., 1987). Penelitian 
lain menunjukkan ekstrak air tempuyung $200 \mathrm{mg} /$ $\mathrm{kgBB}$ dan salam $200 \mathrm{mg} / \mathrm{kgBB}$ dapat menurunkan kadar asam urat masing-masing dari 3,10 $\mathrm{mg} / \mathrm{dL}$ menjadi $0,72 \mathrm{mg} / \mathrm{dL}$ dan $0,52 \mathrm{mg} / \mathrm{kgBB}$. Sedangkan kombinasi kedua ekstrak tersebut pada dosis masing-masing $100 \mathrm{mg} / \mathrm{kgBB}$ dapat menurunkan kadar asam urat sebesar $0,38 \mathrm{mg} / \mathrm{dL}$ (Muhtadi dkk., 2010).

Berdasarkan aktivitas dari kombinasi ekstrak tempuyung (Sonchus arvensis) dan salam (Syzygium polyanthum) dalam menurunkan kadar asam urat, maka diperlukan penelitian lebih lanjut tentang mekanisme penurunan kadar asam urat secara in vivo oleh kombinasi ekstrak air tempuyung (Sonchus arvensis) dan salam (Syzygium polyanthum).

\section{METODE PENELITIAN}

Penelitian yang dilakukan termasuk jenis penelitian eksperimental semu dengan rancangan penelitian acak lengkap pola searah. Variabel penelitian yang digunakan adalah: variabel bebas (Dosis kombinasi ekstrak air tempuyung (Sonchus arvensis) dan salam (Syzygium polyanthum)), variabel tergantung (aktivitas enzim ksantin oksidase), variabel terkendali (Hewan uji diberi makanan buatan (pellet BR), minuman ad libitum, jenis kelamin jantan, galur Swiss, berat badan 26-30 g, umur 2-3 bulan).

Alat: Spuit injeksi volume $1 \mathrm{~mL}$ (Terumo), spuit oral ukuran 18 gange, flakon, timbangan mencit Ohaus kapasitas $610 \mathrm{~g}$, timbangan analitik (Presica A-SCS), sentrifuge (Mikro 200R Hettich), vacum dry oven (J.P. Selecta, s.a), vortex (Maxi Mix II Barnstead), homogenizer (Ultra Turrax), sonifikator 1510 Branson, mikropipet ukuran 5-40 $\mu \mathrm{L} ; 200-1000 \mu \mathrm{L}$, kuvet, alat-alat gelas (Pyrex), alat bedah, dan spektrofotometri UV mini-1240 Shimadzu.

Bahan: Ekstrak air daun tempuyung (RAPID), ekstrak air daun salam (RAPID), es batu, phosphate buffer ( $\mathrm{pH} 7,4)$, EDTA, $\mathrm{HCl}$ $0,58 \mathrm{M}, \mathrm{NaCl} 0,9 \%$ p.a, $\mathrm{KCl}$ p.a, $\mathrm{NaOH} 0,4 \mathrm{~N}$ p.a, tembaga (II) sulfat $1 \%$ p.a, natrium tatrat $2 \%$ p.a, asam fosfotungstat-asam fosfomolibdat p.a, natrium karbonat $2 \%$ p.a, natrium hidroksida $0,1 \mathrm{~N}$ p.a, ammonium sulfat p.a, bovin serum albumin (Aldrich Chemical Company), aquadest, dapar asetat ( $\mathrm{pH}$ 5), pellet, potasium oksonat p.a (Aldrich Chemical Company), allopurinol p.a
(Aldrich Chemical Company), Aqua p.i, ksantin p.a (Aldrich Chemical Company), mencit jantan galur Swiss.

Penentuan Dosis: Dosis allopurinol adalah $10 \mathrm{mg} / \mathrm{kgBB}$ (Muhtadi dkk., 2010). Dosis potasium oksonat adalah $250 \mathrm{mg} / \mathrm{kgBB}$ (Haidari et al., 2009). Dosis ekstrak air kombinasi tempuyung dan salam masing-masing 100 mg/kgBB (Muhtadi dkk., 2010).

Pembuatan Stok Uji dan Potasium Oksonat: Potasium oksonat dibuat dengan konsentrasi $0,5 \%$. Potasium oksonat selalu dibuat baru setiap akan digunakan, kelarutan potasium oksonat adalah $5 \mathrm{mg} / \mathrm{mL}$ dalam air. Sediaan uji, ekstrak diperoleh dengan cara dekocta. Ekstrak kering daun tempuyung dan salam ditimbang seksama dengan konsentrasi masing-masing $1,2 \%$ dalam aquadest. Digunakan sonifikator untuk mempermudah kelarutan.

Pembuatan Hiperurisemia: Hewan uji diadaptasi terlebih dahulu pada lingkungan penelitian selama satu minggu pada suhu kandang. Hewan uji tidak diberi makan 1 jam sebelum penelitian dimulai (Haidari et al., 2009). Pembuatan hiperurisemia dilakukan 1 jam sebelum pemberian sediaan uji dengan menginjeksikan secara i.p potasium oksonat 250 $\mathrm{mg} / \mathrm{kgBB}$ pada jam 07.00 (Haidari et al., 2009).

Desain Pengujian Ekstrak: Sebelumnya dilakukan pembuatan model hiperurisemia dengan cara mencit diinduksi potasium oksonat $250 \mathrm{mg} / \mathrm{kgBB} 1$ jam sebelum perlakuan. Perlakuan dilakukan selama 4 hari. Digunakan 15 ekor mencit yang dibagi menjadi 3 kelompok. 1) Kelompok perlakuan: diinduksi kombinasi ekstrak air tempuyung dan salam masing-masing p.o $100 \mathrm{mg} / \mathrm{kgBB}$. 2) Kontrol positif: diinduksi allopurinol p.o $10 \mathrm{mg} / \mathrm{kgBB}$. 3) Kontrol negatif: diinduksi aquadest p.o 0,5 $\mathrm{mL} / 20 \mathrm{gBB}$. Pembedahan hati dilakukan setelah 2 jam pemberian potasium oksonat, hati segera dicuci dengan $0,9 \% \mathrm{NaCl}$. Hati dibagi menjadi 2 bagian dan ditimbang masing-masing sebanyak $1 \mathrm{~g}$. Selanjutnya hati digunakan untuk penetapan protein dengan metode Lowry dan penetapan aktivitas ksantin oksidase dengan metode spektrofotometri UV.

Penetapan Kadar Protein dengan Metode

Lowry: 1. Pembuatan larutan stok (Larutan stok $0,05 \%$ dibuat dengan menimbang $5 \mathrm{mg}$ bovin serum albumin dan dilarutkan dengan aquadest 10 
$\mathrm{mL}$ ). 2. Penentuan operating time (OT) (Larutan bovin serum albumin $2,5 \times 10^{-3} \%$ dibuat dengan cara diambil $500 \mu \mathrm{L}$ dari larutan stok Lowry kemudian ditambah aquadest $500 \mu \mathrm{L}$, selanjutnya ditambahkan reagen Lowry B $8 \mathrm{~mL}$ ditunggu sampai 10 menit setelah itu ditambah reagen Lowry A $1 \mathrm{~mL}$. Kemudian diukur absorbansinya dengan spektrofotometri UV-Vis setiap 1 menit. Absorbansinya yang paling stabil merupakan OT. OT yang diperoleh adalah 20 menit). 3. Penentuan panjang gelombang maksimum (Larutan bovin serum albumin $2,5 \times 10^{-3} \%$ dibuat dengan cara diambil $500 \mu \mathrm{L}$ dari larutan stok Lowry ditambah aquadest $500 \mu \mathrm{L}$. Kemudian ditambah reagen Lowry B $8 \mathrm{~mL}$ ditunggu sampai 10 menit. Ditambah reagen Lowry A $1 \mathrm{~mL}$ ditunggu 20 menit. Diukur absorbansinya pada spektrofotometri UV-Vis mulai dari $550 \mathrm{~nm}-650$ $\mathrm{nm}$. Absorbansi tertinggi pada panjang gelombang tersebut merupakan panjang gelombang maksimum. Panjang gelombang maksimum yang diperoleh $741 \mathrm{~nm}$. 4. Pembuatan kurva baku Lowry (Kurva baku Lowry dibuat dengan mengambil seri konsentrasi $(0,5 ; 1 ; 1,5 ; 2 ; 2,5$; $3 ; 3,5 ; 4 ; 4,5) \times 10^{-3} \%$ dari larutan stok Lowry, masing-masing ditambah aquadest sampai 1 $\mathrm{mL}$. Ditambah reagen Lowry B $8 \mathrm{~mL}$ ditunggu sampai 10 menit kemudian ditambah reagen Lowry A $1 \mathrm{~mL}$ dan dibiarkan selama 20 menit. Diukur absorbansinya pada $741 \mathrm{~nm}$. Kurva baku standar protein yaitu $\mathrm{y}=15,14 \mathrm{x}+0,01(\mathrm{r}=0,999))$. 5. Penetapan sampel (Segera setelah pembedahan hati dicuci dengan $0,9 \% \mathrm{NaCl}$ dan ditempatkan pada $1,15 \% \mathrm{~b} / \mathrm{v}$ KCl. Hati ditimbang sebanyak $1 \mathrm{~g}$ setelah itu hati dipotong- potong, selama preparasi suhu dijaga tetap pada suhu dingin $\left(4^{\circ} \mathrm{C}\right)$. Ditambahkan $200 \mathrm{mg}$ kristal ammonium sulfat sampai jenuh. Kemudian disentrifuge pada $11.000 \mathrm{rpm}$ selama 10 menit, supernatan dipisahkan. Diambil endapan $\pm 100 \mathrm{mg}$, kemudian dilarutkan dengan dapar asetat pH 5 sampai 10,0 $\mathrm{mL}$. Diambil $400 \mu \mathrm{L}$ sampel dan ditambahkan $8 \mathrm{~mL}$ reagen Lowry $\mathrm{B}$ dibiarkan selama 10 menit. Kemudian ditambah $1 \mathrm{~mL}$ reagen Lowry A dan dibiarkan selama 20 menit. Dibaca pada panjang gelombang $741 \mathrm{~nm}$ (Sudjadi dan Rohman, 2004)).

Penetapan Aktivitas Ksantin Oksidase: 1. Pembuatan larutan stok (Larutan stok ksantin oksidase dibuat dengan menimbang $1,25 \mathrm{mg}$ ksantin oksidase dilarutkan aquadest hingga 100
$\mathrm{mL}(8$ unit/mg)).2. Pembuatan kurva baku ksantin (Kurva baku ksantin dibuat dengan mengambil $(10,20,30,40,50,60,70,80,90) \mu \mathrm{L}$ dari larutan stok ksantin oksidase, di tambah $1 \mathrm{~mL}$ ksantin $5 \mu \mathrm{M}$ kemudian dilarutkan fosfat buffer $50 \mathrm{mM}$ hingga $5 \mathrm{~mL}$. Diinkubasi pada suhu $37^{\circ} \mathrm{C}$ selama 15 menit, selanjutnya ditambahkan $0,5 \mathrm{~mL} \mathrm{HCl}$ $0,58 \mathrm{M}$ dan dibaca absorbansinya pada $\lambda 290$ nm. 1 unit (U) aktivitas ksantin oksidase setara dengan $1 \mu \mathrm{mol}$ ksantin yang diubah menjadi asam urat tiap menit pada suhu $37^{\circ} \mathrm{C}$ dan $\mathrm{pH}$ 7,4 . Kurva baku standar Lowry yaitu $\mathrm{y}=720,9 \mathrm{x}-$ $0,021(\mathrm{r}=0,997))$. 3. Penetapan aktivitas ksantin oksidase (Segera setelah pembedahan hati dicuci dengan $0,9 \% \mathrm{NaCl}$, kemudian ditimbang sebanyak 1 g. Selanjutnya ditempatkan pada campuran $1,15 \% \mathrm{~b} / \mathrm{v} \mathrm{KCl}$ dan $0,1 \mathrm{mMol}$ EDTA. Hati dipotong-potong dan dihomogenasi dalam 4 $\mathrm{mL}$ sodium fosfat $50 \mathrm{mM}$ ( $\mathrm{pH} 7,4)$. Homogenat disentrifuge dengan kecepatan $3000 \mathrm{rpm}$ selama 10 menit. Supernatan disentrifuge kembali dengan kecepatan $15000 \mathrm{rpm}$ selama 60 menit pada suhu $4^{\circ} \mathrm{C}$. Selanjutnya supernatan dipisah dengan endapan pada tabung ependrof. Diambil $100 \mu \mathrm{L}$ supernatan kemudian dicampur $50 \mu \mathrm{M}$ ksantin dan ditambahkan fosfat buffer $50 \mathrm{mM}$ sampai $5 \mathrm{~mL}$. Larutan diinkubasi selama 15 menit pada suhu $37^{\circ} \mathrm{C}$. Dibaca absorbansinya dengan spektrofotometri UV pada $\lambda 290 \mathrm{~nm}$ ).

Data yang diperoleh berupa kadar protein dan aktivitas ksantin oksidase tidak terdistribusi normal dan variansinya tidak homogen setelah dilakukan transformasi maka dilakukan uji nonparametik dengan menggunakan uji Kruskal Wallis dan uji Mann-Whitney dengan taraf kepercayaan 95\%. Penghambatan aktivitas ksantin oksidase diuji dengan uji t tidak berpasangan.

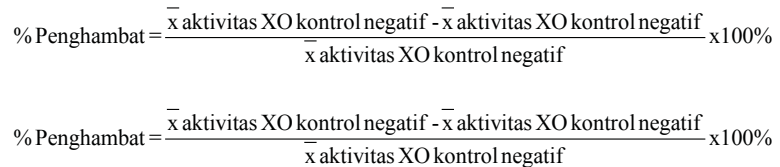

\section{HASIL DAN PEMBAHASAN}

Sediaan uji yang digunakan untuk menurunkan kadar asam urat melalui mekanisme penghambatan enzim oksidase adalah ekstrak air kombinasi tempuyung dan salam dosis masing-masing $100 \mathrm{mg} /$ $\mathrm{kgBB}$. Secara in vitro beberapa flavonoid dapat menghambat enzim ksantin oksidase di antaranya flavonoid luteolin, apigenin, 
kersetin dan miresetin (Gambar 1). Kandungan flavonoid pada ekstrak etanol tempuyung yaitu 5,7,3',4'-tetrahidroksi flavon (luteolin), 5,7,4'-trihidroksi flavon (apigenin), luteolin 7-O-glukosida, dan apigenin 7-O-glukosida (Djunaedi dkk., 2003). Flavonoid luteolin dapat menghambat ksantin oksidase dengan nilai IC50 sebesar $0,96 \mu \mathrm{M}$ dan $0,55 \mu \mathrm{M}$, sedangkan apigenin memiliki IC50 sebesar 29,1 $\mu \mathrm{M}$ dan $0,70 \mu \mathrm{M}$ (Nagao et al., 1999; Cos et al., 1998). Daun salam diduga mengandung flavonoid kuersetin dan miresetin (Schemeda et al., 1987). Hasil penelitian menunjukkan bahwa flavonoid kuersetin memiliki IC50 sebesar 0,44 $\mu \mathrm{M}$ dan 2,62 $\mu \mathrm{M}$, sedangkan nilai IC50 miresetin sebesar $1,27 \mu \mathrm{M}$ dan 2,38 $\mu \mathrm{M}$ (Nagao at al., 1999; Cos at al., 1998). Hasil penelitian lain menunjukkan bahwa kuersetin pada dosis 50 dan $100 \mathrm{mg} / \mathrm{kgBB}$ menunjukkan penghambatan ksantin oksidase yang siginifikan pada tikus hiperurisemia (Mo Shi-Fu, 2007).

Senyawa flavonoid dapat menghambat ksantin oksidase disebabkan oleh adanya gugus hidroksil pada atom C-5 atau C-7 serta adanya ikatan rangkap antara $\mathrm{C}-2$ dan $\mathrm{C}-3$ yang memungkinkan terjadi reaksi adisi (oksidase oleh ksantin oksidase) sehingga cincin B menjadi co-planar terhadap cincin A dan C (Cos et al., 1998). Kemampuan flavonoid dalam menghambat aktivitas ksantin oksidase yaitu melalui mekanisme inhibisi kompetitif dan interaksi dengan enzim pada gugus samping (Nagao et al., 1999; Lin et al., 2002).
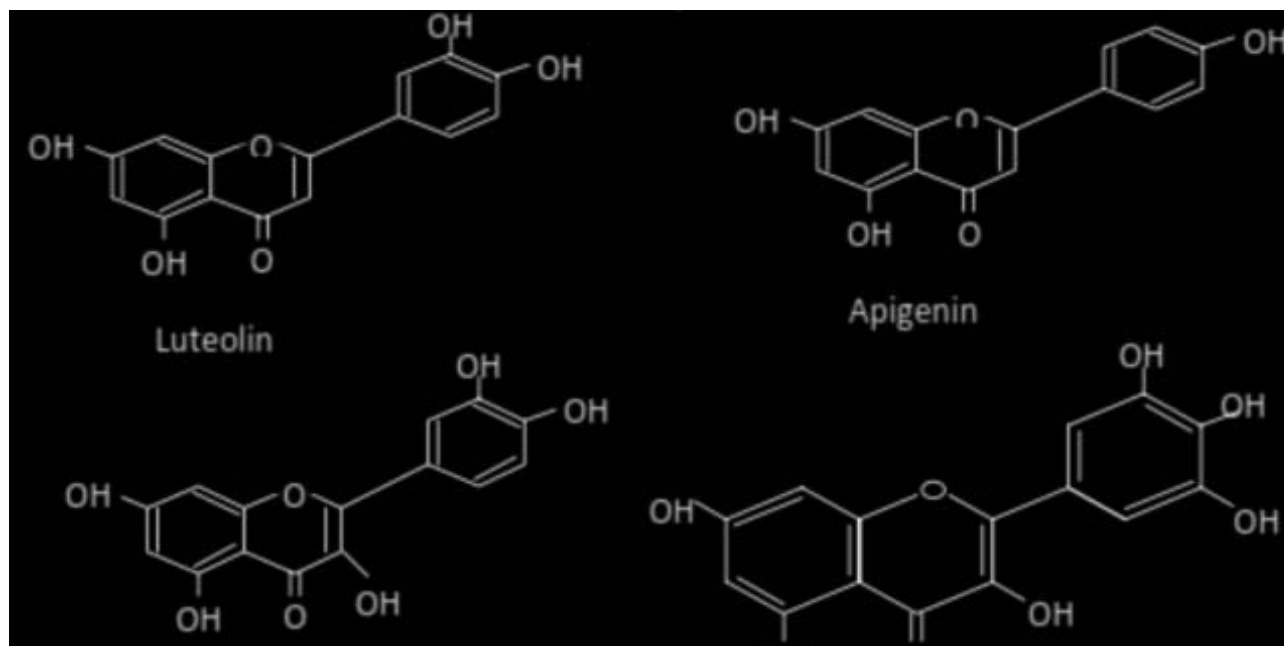

Apigenin

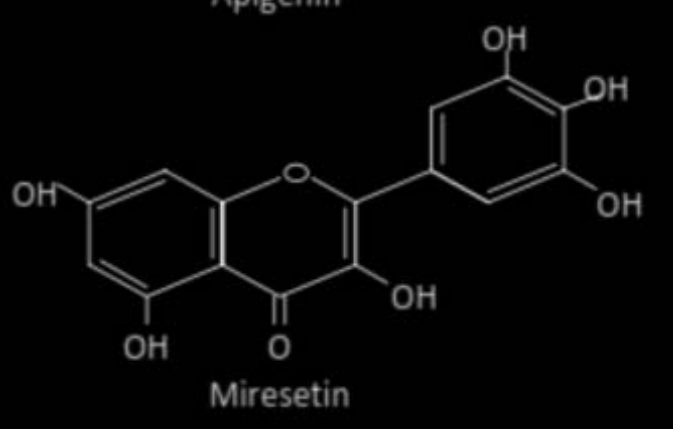

Gambar 1. Struktur Flavonoid Flavon (Apigenin, Luteolin) dan Flavonol (Kuersetin, Miresetin)

Tabel 1. Data Kadar ksantin oksidase, kadar protein, aktivitas ksantin oksidase dan persentase penghambatan ksantin oksidase pada kontrol positif, kontrol negatif dan kombinasi tempuyung-salam

\begin{tabular}{|c|c|c|c|c|c|}
\hline \multirow{2}{*}{ Perlakuan } & \multirow{2}{*}{ No. HU } & Kadar XO & Kadar Protein & Aktivitas XO & \multirow{2}{*}{$\begin{array}{c}\text { Persentase } \\
\text { Penghambatan } \\
(\%)\end{array}$} \\
\hline & & (U/g hati) & (g protein/g hati) & (U/g protein) & \\
\hline \multirow[t]{5}{*}{ Kontrol Positif } & 1 & 0,09 & 0,12 & 0,80 & 90,03 \\
\hline & 2 & 0,10 & 0,12 & 0,82 & 89,71 \\
\hline & 3 & 0,09 & 0,12 & 0,79 & 90,14 \\
\hline & 4 & 0,09 & 0,13 & 0,76 & 90,47 \\
\hline & 5 & 0,09 & 0,12 & 0,75 & 90,63 \\
\hline $\mathrm{X} \pm \mathrm{SE}(\mathrm{mg} / \mathrm{mL})$ & & $0,09 \pm 0,00$ & $0,12 \pm 0,00^{*}$ & $0,78 \pm 0,01 *$ & $90,20 \pm 0,16^{*}$ \\
\hline \multirow[t]{5}{*}{ Kontrol Negatif } & 1 & 0,19 & 0,02 & 8,11 & - \\
\hline & 2 & 0,20 & 0,03 & 8,04 & - \\
\hline & 3 & 0,20 & 0,02 & 8,08 & - \\
\hline & 4 & 0,19 & 0,03 & 7,62 & - \\
\hline & 5 & 0,20 & 0,03 & 8,15 & - \\
\hline $\mathrm{X} \pm \mathrm{SE}(\mathrm{mg} / \mathrm{mL})$ & & $0,20 \pm 0,00$ & $0,03 \pm 0,00^{\#}$ & $8,00 \pm 0,10^{\#}$ & \\
\hline
\end{tabular}




\begin{tabular}{|c|c|c|c|c|c|}
\hline \multirow{5}{*}{ Tempuyung-Salam } & 1 & 0,10 & 0,02 & 4,58 & 42,79 \\
\hline & 2 & 0,11 & 0,03 & 4,26 & 46,77 \\
\hline & 3 & 0,12 & 0,03 & 3,41 & 57,38 \\
\hline & 4 & 0,13 & 0.03 & 3.75 & 53,10 \\
\hline & 5 & 0,14 & 0,04 & 3,54 & 55,76 \\
\hline $\mathrm{X} \pm \mathrm{SE}(\mathrm{mg} / \mathrm{mL})$ & & $0,12 \pm 0,00$ & $0,03 \pm 0,00^{* * \#}$ & $3,91 \pm 0,22^{* \#}$ & $51,16 \pm 2,76^{*}$ \\
\hline
\end{tabular}

Keterangan :

(*): $\quad$ Berbeda bermakna terhadap kontrol negatif jika $\mathrm{p}<0,05$

(\#): $\quad$ Berbeda bermakna terhadap kontrol positif jika $\mathrm{p}<0,05$

Hasil uji Mann-Whitney menunjukkan bahwa kadar protein pada allopurinol lebih besar secara signifikan dibandingkan kontrol negatif $(\mathrm{p}=0,008)$ maupun pada kombinasi tempuyungsalam $(\mathrm{p}=0,008)$. Sedangkan antara kontrol negatif dan kombinasi tempuyung-salam tidak terdapat perbedaan jumlah kadar protein secara signifikan $(p=0,151) \quad$ (Tabel 1). Hal ini sesuai dengan penelitian sebelumnya bahwa setelah pemberian allopurinol pada sel hamster diperoleh kadar protein sebesar $12,82 \mathrm{mg}$ protein $/ \mathrm{mL}$ enzim sedangkan dengan pemberian asam urat hanya memperoleh kadar protein sebesar 9,45 $\mathrm{mg}$ protein/mL enzim (Brunschede dan Krooth, 1973). Pada aktivitas ksantin oksidase diperoleh bahwa allopurinol $10 \mathrm{mg} / \mathrm{kgBB}$ dan kombinasi ekstrak air tempuyung-salam masing-masing $100 \mathrm{mg} / \mathrm{kgBB}$ mampu menurunkan aktivitas enzim ksantin oksidase secara signifikan jika dibandingkan dengan kontrol negatif $(\mathrm{p}=0.008)$.

Hasil uji statistik dengan uji $t$ pada penghambatan aktivitas ksantin oksidase menunjukkan pemberian kombinasi ekstrak tempuyung-salam masing-masing $100 \mathrm{mg} / \mathrm{kgBB}$ dapat menghambat aktivitas ksantin oksidase sebesar 51,16\% sedangkan pada allopurinol sebesar $90,20 \% \quad(p=0,000)$. Penelitian lain menunjukkan secara in vivo ekstrak air daun tempuyung $200 \mathrm{mg} / \mathrm{kgBB}$ menunjukkan penghambatan sebesar 70,30\% (Frastyowati, 2012) sedangkan ekstrak air daun salam 200 $\mathrm{mg} / \mathrm{kgBB}$ memberikan penghambatan sebesar 23,67\% (Wahyudin, 2012). Hal ini disebabkan karena dosis pada kombinasi tempuyung- salam lebih rendah dibandingkan dosis tunggalnya sehingga efek yang dihasilkan tidak mencapai hasil yang optimal. Selain itu, secara in vitro senyawa luteolin pada daun tempuyung memiliki aktivitas inhibisi paling kuat (Cos et al., 1998), sedangkan menurut Biesaga M., (2011) senyawa miresetin pada daun salam mudah terdegradasi pada pemanasan refluks selama 30 menit di waterbath dan microwive di bawah $160 \mathrm{~W}$ selama 1 menit sehingga diduga menyebabkan efek penghambatan salam lebih kecil dibandingkan tempuyung. Kemungkinan lain bahwa adanya senyawa-senyawa selain flavonoid yang ikut tersari yang dapat mengganggu aktivitas senyawa aktif pada ekstrak tempuyung-salam.

Efek penurunan asam urat pada ekstrak air kombinasi tempuyung-salam dosis masingmasing $100 \mathrm{mg} / \mathrm{kgBB}$ lebih besar dibandingkan dengan ekstrak air tempuyung-salam $200 \mathrm{mg} /$ kgBB (Muhtadi dkk., 2010) sehingga dapat dikatakan kemungkinan salam memiliki efek urikosurik dalam menurunkan kadar asam urat maka perlu dilakukan penelitian lebih lanjut.

Penelitian lain terhadap penurunan asam urat melalui penghambatan ksantin oksidase diantaranya pada kombinasi ekstrak air tempuyung-jinten hitam dosis masing-masing $100 \mathrm{mg}$ secara in vivo dapat menghambat aktivitas ksantin oksidase sebesar 43,26\% (Heryani, 2012). Berdasarkan penelitian tersebut terbukti bahwa kombinasi ekstrak air tempuyung-salam dosis masing-masing 100 $\mathrm{mg} / \mathrm{kgBB}$ berpotensi sebagai inhibitor ksantin oksidase $(51,16 \% \pm 2,76 \%$, ) karena memiliki daya inhibisi lebih besar sehingga dapat dikembangkan sebagai obat antihiperurisemia.

Kelemahan dari penelitian ini yaitu tidak adanya kontrol normal (hewan uji yang tidak diberi potasium oksonat) sehingga tidak dapat dilihat perbedaan aktivitas ksantin oksidase pada hewan uji normal dan hiperurisemia.

\section{KESIMPULAN}

Kombinasi ekstrak air tempuyungsalam pada dosis masing-masing $100 \mathrm{mg} / \mathrm{kgBB}$ memiliki aktivitas ksantin oksidase sebesar 3,91 $\mathrm{U} / \mathrm{g}$ protein dan dapat menghambat ksantin oksidase sebesar $51,16 \% \pm 2,76 \%$ sedangkan allopurinol sebesar $90,20 \% \pm 0,16 \%$. 


\section{SARAN}

1. Perlu dilakukan isolasi dan identifikasi senyawa aktif pada ekstrak air tempuyung dan salam yang bertanggung jawab dalam penghambatan enzim ksantin oksidase.

2. Perlu dilakukan penelitian lebih lanjut tentang efek urikosurik pada kombinasi ekstrak air tempuyung dan salam.

3. Perlu dilakukan kontrol normal untuk mengetahui perbedaan aktivitas ksantin oksidase pada hewan uji normal dan hiperurisemia.

\section{DAFTAR PUSTAKA}

Brunschede, H. \& Krooth, R.S., 1973, Studies on the Xanthine Oxidase Activity of Mammalian Cells, Biochemical Genetics, 8(4).

Biesaga, M., 2011, Influence of Extraction Methods on Stability of Flavonoids, Journal Chromatogr A., Department of Chemistry, University of Warsaw, Poland 1216(18), 2505-2512.

Cos, P., Ying, L., Calomme, M., Jia, P. Hu, Cimanga, K., Van P. B., Pieters, L., Arnold J., Vlietinck, and Berghe V., Dirk, 1998, StructureActivity Relationship and Classsification of Flavanoid as Inhibitors of Xanthine oxdase and Superoxide Scavengers, Journal of Natural Products, Department of pharmaceutical sciences, University of Antwerp, Belgium.

Dipiro, J.T., Robert, L.T., Gary, C.Y., Gary, R.M., Barbara, G.W., Michael, P.L., 2008, Pharmacotherapy A Pathophysiologic Approach Seven Edition, Mc Graw Hill Medical, New York, 1572-1573.

Djunaedi, D.D., Padmawinata K., Soediro I., Yulinah S. E., 2003, Efek antibatu Kemih Orthosiphon aristatus (BI.)Miq., Sonchus arvensis L., Phyllanthus niruri L., dan Campurannya serta Isolasi dan Identifikasi Senyawaa dari Sonchus arvensis L., Disertasi, Fakultas Farmasi ITB, Bandung.

Frastyowati, H., 2012, Penghambatan Xanthin Oxidase Oleh Ekstrak Tempuyung (Sonchus arvensis) Terhadap Mencit Hiperurisemia, Skripsi, Fakultas Farmasi, Universitas Muhammadiyah Surakarta, Surakarta.

Haidari, F., Rashidi, M., Reza, Keshavarz, S. A., Shahi, M. M., 2009. Orange Juice and Hesperetin Supplementation to Hyperuricemic Rats Alter Oxidative Stress Markers and Xanthine Oxidoreductase
Activity. J. Clin. Biochem. Nutr. Volume 45. 285-291.

Heryani, S., 2012, Penghambatan Ksantin Oksidase Oleh Ekstrak Kombinasi Tempuyung (Sonchus arvensis) dan Jintan Hitan (Nigella sativa) Pada MencitHiperurisemia, Skripsi, Fakultas Farmasi, Universitas Muhammadiyah Surakarta, Surakarta.

Lin CM, Cheng CS, Chen CT, Liang YC, Lin JK, 2002, Molecular Modeling of Flavonoid That Inhibitors Xanthin Oxidase. Biocheml Biophys Res Com. 294:167-172.

Mazzali, M., Kanallis J., Han L., Feng L., Yang Xia Li, Chen Q., Duk- Hee Kang, katherine L., Gardon, Watanabe S., Nakagawa T., Lan and Richard J. Johnson., 2001, Hyperuricemia Induces A Primary Renal Arteriolopathy in Rats By A Blood Preassure-independent Mechanism, Division of Nephrology, Baylor College of Medicine, Houston, Texas 77030.

Mo, Shi-Fu, Zhou, Feng, Lv, Yao-Zhou, Hu, Qing-Hua, Zhang, Dong-Mei, Kong, Ling-Dong, 2007, Hypouricemic Aktion of Selected Flavonoid in Mice: Structure-Activity Relationships, Biol. Pharm. Bull., Vol. 30, No. 8, 15511556

Muhtadi, Sutrisna, E.M., Wahyuningtyas, N., Suhendi A., 2010, , Pembangunan Agen Fitoterapi Asam Urat Dari Tumbuhan Obat Indonesia Untuk Peningkatan Kapasitas Bahan Alam Obat Menjadi Produk Obat Herbal Terstandr (OHT), Laporan Akhir Tahun Pertama Riset Andalan Perguruan Tinggi dan Industri (RAPID), Direktorat Jendral Pendidikan Tinggi Departemen Pendidikan Nasional, Jakarta.

Mutschler, E., 1991, Dinamika Obat, Buku Ajar Farmakologi dan Toksikologi, Edisi Kelima, ITB, Bandung, 220-221.

Nagao, Akihiko, Seki, Michiko, Kobayashi, Hidetaka, 1999, Inhibition of Xanthin Oxidase by Flavonoid, Biosci. Biotechnol, biochem, Japan.

Nordstrom, G., Seeman, T., Hasselgren P,O., 1985, Beneficial Effect of Allopurinol in Liver Ischemia, Sugery, 97 (6), 679-684.

Heryani, S., 2012, Penghambatan Ksantin Oksidase Oleh Ekstrak Kombinasi Tempuyung (Sonchus arvensis) dan Jintan Hitan (Nigella sativa) Pada MencitHiperurisemia, Skripsi, Fakultas Farmasi, Universitas Muhammadiyah Surakarta, Surakarta. 
Priyanto dan Batubara, 2008, Farmakologi Dasar, Cetakan Pertama, Leskonfi, Jakarta, 107-108.

Rose, L. F., Kaye, D., 1997, Buku Ajar Penyakit Dalam Untuk Kedokteran Gigi, Jilid 1, Edisi 2, Binarupa Aksara, Jakarta, 99.

Schemeda H. G., Theoduloz, C., Fransco, L., Ferro, E., Arias, A. R., 1987, Preliminary pharmalogical studies on eugenia uniflora leaves: xanthine oxidase inhibitory activity, $J$ Ethnopharmacol, 21(2): 183-186.

Sudarsono, Gunawan, D., Wahyuono, S., Donatus, A. I., dan Purnomo, 2002, Tumbuhan Obat II Hasil Penelitian, Sifat-sifat dan Penggunaan, Pusat Studi Obat Tradisional, Universitas Gadjah Mada, Yogyakarta, 174-175.

Sudjadi dan Rohman, A., 2004, Analisis Obat dan Makanan, Pustaka Pelajar, Yogjakarta, 125-126.
Wahyudin, M. W., 2012, Aktivitas Penghambatan Ksantin Oksidase Ekstrak Daun Salam (Syzygium polyanthum) Pada Mencit yang Diinduksi Kalium Oksonat, Skripsi, Fakultas Farmasi, Universitas Muhammadiyah Surakarta, Surakarta.

Wardani, C. G. T., 2008, Potensi Ekstrak Tempuyung dan Meniran Sebagai Anti Asam Urat: Aktivitas Inhibisinya Terhadap Xanthin Oksidase, Skripsi, Fakultas Matematika dan Ilmu Pengetahuan Alam, Institut Pertanian Bogor, Bogar.

Winarto, W. P., dan Karyasari, 2004, Tempuyung Tanaman Penghancur Batu Ginjal, Agromedia Pustaka, Jakarta, 2-3. 